Relations industrielles

Industrial Relations

\title{
The Influence of External Information on Collective Bargaining: Survey Evidence of Union and Firm Negotiators in the Netherlands
}

\author{
L'influence de l'information externe sur la négociation \\ collective : résultats d'une enquête auprès de négociateurs \\ syndicaux et patronaux aux Pays-Bas \\ La influencia de la información externa sobre la negociación \\ colectiva: Resultados de una encuesta con negociadores \\ sindicales y patronales en los Países Bajos
}

\author{
Alex Lehr, Agnes Akkerman et René Torenvlied
}

Volume 70, numéro 2, printemps 2015

URI : https://id.erudit.org/iderudit/1031488ar

DOI : https://doi.org/10.7202/1031488ar

Aller au sommaire du numéro

Éditeur(s)

Département des relations industrielles de l’Université Laval

ISSN

0034-379X (imprimé)

1703-8138 (numérique)

Découvrir la revue

Citer cet article

Lehr, A., Akkerman, A. \& Torenvlied, R. (2015). The Influence of External Information on Collective Bargaining: Survey Evidence of Union and Firm Negotiators in the Netherlands. Relations industrielles / Industrial Relations, 70(2), 327-352. https://doi.org/10.7202/1031488ar
Résumé de l'article

Cet article cherche à répondre à deux questions : 1- dans quelle mesure les personnes négociant une convention collective sont-elles influencées par divers types d'information externe; et 2- comment les différences d'influence de l'information externe entre les personnes négociatrices peuvent être expliquées par les caractéristiques de ces personnes et les unités de négociation. Un questionnaire standardisé cherchant à mesurer les influences auto-déclarées de divers types d'information externe a été développé et administré à un échantillon représentatif de négociateurs et négociatrices de syndicats et d'employeurs dans les Pays-Bas. Au total, 123 négociateurs ont participé à l'enquête.

Quatre types d'information externe ont été étudiés : 1- information de nature économique; 2- information relative au pouvoir organisationnel; 3information de nature institutionnelle; et 4 information relative aux effets de débordement des négociations. Les analyses descriptives montrent que l'information de nature économique, particulièrement au niveau sectoriel, s'avère très influente, tout comme l'information de nature institutionnelle portant sur les développements nationaux et sectoriels des conventions collectives. L'information reflétant le pouvoir organisationnel, tel le militantisme, aurait moins de poids, alors que l'information concernant d'autres aspects liés à la négociation — par exemple, l'effet de débordement s'avère très important.

Selon la théorie existante provenant de résultats de recherches empiriques et d'hypothèses couramment admises dans la littérature des relations de travail, cet article développe et vérifie un certain nombre d'hypothèses concernant l'influence de l'information externe. Il s'avère que l'influence des effets de débordement s'accroit à mesure qu'on se rapproche de leur source. De plus, les négociateurs syndicaux sont généralement davantage influencés par l'information externe que leurs vis-à-vis patronaux. Il appert aussi que l'influence s'accroît avec l'expérience, bien que cet effet demeure modeste. L’idée que les personnes négociant au niveau sectoriel sont moins influencées par l'environnement économique que celles négociant au niveau de l'entreprise n'est pas vraiment accréditée par les résultats. Dans cette enquête, il ressort qu'elles sont moins influencées par les effets de débordement et par les développements de convention collective au niveau international.
Tous droits réservés (C Département des relations industrielles de l’Université Laval, 2015
Ce document est protégé par la loi sur le droit d'auteur. L’utilisation des services d’Érudit (y compris la reproduction) est assujettie à sa politique d'utilisation que vous pouvez consulter en ligne.

https://apropos.erudit.org/fr/usagers/politique-dutilisation/ 


\section{The Influence of External Information on Collective Bargaining: Survey Evidence of Union and Firm Negotiators in the Netherlands}

\section{Alex Lehr, Agnes Akkerman and René Torenvlied}

External information is generally assumed to greatly affect collective bargaining, yet rigorous empirical investigations of the influence of this information on union and firm negotiators are surprisingly scarce. Comprehensive standardized survey data measuring the influence of external information on negotiators in the Netherlands were analyzed to reveal the extent to which negotiators were influenced by different types of external information and how differences in these influences could be explained by the characteristics of negotiators and bargaining units. The findings indicate that the influence of external information a) increased with proximity of the information source; b) was usually greater for union negotiators than for firm negotiators; and in some cases c) modestly increased with negotiator experience; and d) was greater in company bargaining than in sector bargaining.

KEYWORDS: collective bargaining, negotiators, information, survey, spillover.

\section{Introduction}

Theories explaining the outcomes of and conflicts in labour contract negotiations commonly model the behaviour of actors that have the power to take decisions at the bargaining table, i.e. the negotiators, as a function of their knowledge and evaluation of various types of information (e.g. Walton and McKersie, 1965: 44, 61-63; Dunlop, 1957). Such information may either be internal (characteristics of the bargaining event itself), or external (contextual characteristics of the bargaining event) (c.f. Blanchflower and Oswald, 1988; Abowd, 1989).

Alex Lehr, Researcher and Lecturer, Institute of Management Research, Department of Political Science, Radboud University, Nijmegen, Netherlands (a.lehr@fm.ru.nl).

Agnes Akkerman, Professor, Department of Sociology, Vrije Universiteit Amsterdam and Groningen University, Netherlands (agnes.akkerman@vu.nl).

René Torenvlied, Professor, Department of Public Administration, Twente University, Enschede, Netherlands (r.torenvlied@utwente.nl).

The authors acknowledge financial support from the Conflict and Security program of the Netherlands Organization for Scientific Research (NWO), grant \#432-08-022 and from the Nijmegen School of Management, Radboud University, the Netherlands. 
Despite the central role attributed to the influence of information on negotiators, rigorous empirical analyses of this influence are scarce. Many studies instead rely on anecdotal evidence or opt to simply build on a priori assumed influences. To the extent that direct empirical evidence of the influence of information on negotiators does exist, it is usually limited to one side of the bargaining table, ignoring that bargaining is a joint decision-making process. In this paper, we present a systematic study of the influence of different types of external information on union and firm negotiators in collective bargaining in the Netherlands, and offer explanations for the variation in this influence.

Our first goal was to answer the following question: to what extent are negotiators in collective bargaining influenced by different types of external information? We developed a questionnaire survey measuring self-reported influences of different types of external information on union and firm negotiators. A particular strength of our survey is that it offers an extensive, standardized analysis of the direct impact of spillovers from the past and from other bargaining units on negotiators, circumventing identification problems associated with establishing such effects (c.f. Mitchell, 1982; Heckman, 1991; Manski, 1993).

The extent to which external information affects bargaining behaviour is likely to vary across different types of negotiators (c.f. Ashenfelter and Johnson, 1969, Mauro, 1982) and different types of bargaining units (c.f. Cousineau and Lacroix, 1986). The second goal of our study was therefore to shed light on a second question: how can differences in the reported influence of external information between negotiators be explained by the characteristics of the negotiators and bargaining units? To our knowledge, this is the first comprehensive quantitative analysis of variations in the influence of external information on negotiators in collective bargaining.

\section{Theory and hypotheses}

Bargaining theory typically assumes that negotiators do not have complete information on critical aspects of the bargaining event they are involved in. In collective bargaining, these critical aspects are bargaining power (Leap and Grigsby, 1986; Svejnar, 1986; Cousineau and Lacroix, 1986; Martin, 1992), employers' ability to pay (Hayes, 1984; Cramton and Tracy, 2003) and norms concerning fair outcomes (Hyman and Brough, 1975; Frank, 1984; Rees, 1993). As negotiators aim to overcome their uncertainty regarding such aspects, they turn to external information that may serve as a proxy. We distinguish four types of external information: 1- economic information, 2- information on organizational power, 3- institutional information, and 4- information spillovers.

In the following section, we explain our selection of the types of external information in our analysis, based on common assumptions and findings of 
labour relations research. Because we aim to provide standardized measurements, this selection is by necessity not exhaustive and we recognize that other relevant indicators may be suggested. Following the presentation of the chosen types of external information, we develop testable hypotheses concerning the influence of external information from extant theory, common assumptions and empirical findings.

\section{Types of external information}

Empirical studies consistently find a relationship between economic factors and collective bargaining outcomes and conflicts, as bargaining strategies are shaped by negotiators' perceptions of these factors. The economic indicators most commonly found to affect collective bargaining are prices and employment (Franzosi, 1989; Card, 1990; Kaufman, 2002; Cramton and Tracy, 2003). Therefore, we investigated the influence of information on employment and pricing developments on negotiators. We distinguished between different levels at which these developments operate and analyzed those that were most pertinent for each type of factor within our empirical context. For employment, this entailed differentiating between national, sectoral and local developments. For pricing, we focused on international, national and sectoral developments.

Organizational power also substantially affects collective bargaining (Franzosi, 1989; c.f. Shorter and Tilly, 1974). At the macro level, unionization is the primary factor of interest, as it reveals crucial information on unions' ability to mount collective action. However, as we were concerned with factors that affect the behaviour of individual negotiators, there may be more informative indicators of power. ${ }^{1}$ The first indicator we considered was militancy, defined as the readiness of employees to partake in industrial action. ${ }^{2}$ If employees are more willing to partake in industrial action, the ability of a union to inflict costs upon the firm through strike action will increase, giving them relatively more leverage. Similarly, strike funds determine the power of the union vis-à-vis the firm (Clegg, 1976; Skeels and McGrath, 1997). Public opinion can also influence bargaining power, as the public's reaction to a firm's behaviour during collective bargaining may hurt sales while unions may depend on public support to mobilize workers (Chamberlain and Kuhn, 1986: 189-191). We therefore studied the influence of information on three organizational power factors: a- workers' readiness for industrial action; b- union strike funds; and c- public opinion.

The third type of external information we considered was related to institutional factors. Here, it was important to consider the specifics of the Dutch case. In the Netherlands, collective bargaining occurs at both the company and sector level, with the sector level being dominant and sector level contracts sometimes setting a framework for company level bargaining (EIRO, 2008). Moreover, col- 
lective bargaining is multileveled, as central agreements of labour and employer peak organizations provide a non-legally binding benchmark for both company and sector level agreements (Torenvlied and Akkerman, 2004). Through ILO conventions, the European Social Charter, and a more general trend towards Europeanization of employment relations (Brandl and Traxler, 2009; EUROFOUND, 2012), collective bargaining is also affected by international developments. Given this complex context, we chose the focus our analyses of external information on developments related to collective agreements on five levels: a- international; b- national; c- sectoral; d- local; and e- comparable companies.

External information related to collective agreement developments may not only reflect institutional aspects. Although pattern bargaining, i.e. reiterated, longterm stable and explicit co-ordination (c.f. Traxler et al., 2008) does not feature prominently in the Netherlands (Van Rij and Rojer, 1998), different collective agreements are not independent of each other. Information on other bargaining events affects negotiators through spillovers. Traditionally, spillovers have been associated with the influence of specific information on bargaining outcomes, i.e. wages, across different bargaining units (e.g. Christofides et al., 1980; Babcock et al., 2005). Yet spillover may also occur over time within bargaining units, for instance, because past settlements affect future settlements directly, leading to history-dependence (Card, 1990, Bewley, 1999). Moreover, spillovers across and within bargaining units are not limited to outcomes. Negotiators also take into account information on conflicts and conflict potential (e.g. Mauro, 1982; Schnell and Gramm, 1987; Campolieti et al., 2005; Kuhn and Gu, 1999). We investigated this complex array of spillovers by measuring the influence of information on: a- outcomes; b- employees' readiness for industrial action; and c- the success of industrial action. We differentiated each of these types of informational content according to the following three potential sources: a- the same bargaining unit in the past; $b$ - other bargaining units in the same sector; and c- other sectors.

\section{Spillovers and proximity}

Spillovers from different sources are likely to have different relevance. Wage spillovers have traditionally been considered to be a phenomenon that occurs within sectors. The implicit argument is that for spillovers to occur, information must be sufficiently relevant. For instance, spillovers driven by social comparisons (e.g. Babcock et al., 2005) arise because workers take the wages of workers in other bargaining units as relevant reference points (c.f. Tversky and Kahneman, 1981) if these other workers closely resemble themselves (c.f. Festinger, 1954). Alternatively, spillovers may also be driven by a process of rational learning (Kuhn and Gu, 1999), which can only occur if the outcomes and conflicts of bargaining in one bargaining 
unit reveal private information in other bargaining units because this information is correlated within sectors(Lehr and al., 2013). Spillovers within sectors may thus be expected to have more influence than spillovers across sectors. However, the most important reference point for current wages are past wages within the bargaining unit (Bewley, 1999). Similarly, past conflict (potential) in a bargaining unit is presumably the best indicator for future potential outcomes of conflict.

Ordering sources of spillover by their proximity to the current bargaining event, we expected that information on the past experience of the bargaining unit would have the most influence on negotiators, followed by information on the experience of other bargaining units within the same sector, while information on the experience of other sectors would have the least influence ( $\mathrm{H} 1)$.

\section{Union and firm negotiators}

A common assumption in bargaining theory is that one bargaining party will have better information than the other, i.e. information is asymmetric. Asymmetric information models became a standard solution to the Hicks (1932) bargaining paradox in the 1980s, and remain highly influential. Bargaining is thought of as the division of an economic surplus between the firm(s) and workers represented by their union(s) (Cramton and Tracy, 2003). The critical aspect of the bargaining event is the firm's ability to pay, which is commonly assumed to be known to firms but can only be estimated by unions (Hayes, 1984). Alternatively, it has been argued that it is actually the employer's willingness rather than ability to pay that characterizes wage bargaining (Bewley, 1999). Regardless of this distinction, unions are generally thought of as being at an informational disadvantage.

Moreover, through their actions in the bargaining process, negotiators reveal information on their willingness to concede. In practise, trade unions formulate a demand that firms can respond to by acceptance or a counteroffer. This allows firms to learn about the union's willingness to concede before revealing their own, adding to the uncertainty that unions face relative to the uncertainty that firms face.

Therefore the need to reduce uncertainty by using external information should be higher among union negotiators than among firm negotiators and we expected that external information would have more influence on union negotiators than on firm negotiators ( $\mathrm{H} 2$ ).

\section{Experience}

There are two different possible accounts of the relationship between negotiator experience and the influence of external information. Montgomery and Benedict (1989) argue that more experienced negotiators are less likely to experience strikes because experienced negotiators are better able to ascertain the true value 
of the unobservable aspects critical to reaching an agreement. Similarly, Reder and Neuman (1980) propose that bargaining units consisting of more experienced negotiators are less likely to strike because negotiators learn to anticipate each other's behaviour. It may therefore be argued that experience reduces negotiators' uncertainty, which in turn limits their need for external information.

This leads us to the following hypothesis: the more experience negotiators have, the less they are influenced by external information (H3A).

However, it is equally plausible to argue the reverse. Reder and Neuman (1980) maintain that in bargaining units that bargain repeatedly, negotiators learn from past bargaining events. This may be interpreted as spillover within the bargaining unit over time. Anecdotally, Rees (1993) illustrates how, through his repeated personal involvement in wage setting, he became aware of the importance of external wage comparisons. More generally, it may be argued that, as negotiators become more experienced, they learn to use external information and consequently face less uncertainty.

We therefore propose the alternative hypothesis that the more experience negotiators have, the more they are influenced by external information (НзB).

\section{Bargaining level}

In the Netherlands, there is a mix of single and multi-employer bargaining. Following Olson's (1982) idea that organized interest is most disruptive to society when it is strong enough to have considerable impact without being so encompassing that it substantially bears the costs it creates, Calmfors and Driffhill (1988) argue that there is a hump-shaped relationship between the level of bargaining centralization and economic performance. Their theory yields predictions for comparisons of different industrial relations systems, however, it may also yield propositions for within-country comparisons. Calmfors and Driffhill argue that that decentralized, i.e. company level bargaining, is largely subject to market forces, while intermediate levels of centralization, i.e. sector level bargaining, can operate in relative independence from its economic environment. Assuming perfect product-market competition, a single company in isolation cannot raise wages without incurring decreased competitiveness and employment. Sector-level bargaining, on the other hand, allows negotiators to pass on negative externalities because they can jointly raise prices. We may thus expect that, compared to company-level bargaining, sector-level bargaining is primarily concerned with developments within the sector and takes place under relative autonomy from its economic environment.

Therefore, we tested the hypothesis that information on international, national and local economic developments will have less influence on negotiators in sector agreements than on negotiators in company agreements $(\mathrm{H} 4)$. 
Sector-level bargaining is dominant in the Netherlands and sector agreements often set the framework for company level bargaining. Moreover, company bargaining is prevalent in particular branches and regions, such as transport and storage in the Rotterdam harbour. This induces direct labour-market competition among these bargaining units as well as a high level of interdependence of organizationally derived bargaining power, e.g. correlated militancy and strike funds.

Hence we expected that local collective agreement developments, collective agreement developments in comparable companies and spillovers across bargaining units would have more influence on negotiators in company agreements than on negotiators in sector agreements (H5).

\section{The empirical context}

The Netherlands features state-sponsored coordination (Traxler, 2003) with bipartite and tripartite consultation. Non-binding central agreements that serve as benchmarks for lower level bargaining (Akkermen and Torenvlied, 2002) are negotiated in the bipartite Labour Foundation (Stiching van de Arbeid). Tripartite processes take place in the Social Economic Council (Sociaal Economische Raad), which advises on general social economic decisions (EIRO, 2008).

Approximately 1000 collective agreements are in effect and roughly one fifth of these are sector agreements. Approximately 84 percent of the labour force is covered by a collective agreement (EIRO, 2008), four fifths of which through sector agreements. In some sectors, there are both company and sector level agreements. High collective bargaining coverage is maintained despite the trade union density being comparatively low at approximately $24 \%$ (EIRO, 2008) because collective agreements apply to both unionized and non-unionized workers in a workplace and because the extension of collective agreements to whole sectors is common (c.f. Rojer, 2002). The three major Dutch trade union federations are divided by religion, ideology and occupational status. Collective bargaining often involves more than one union (Akkerman, 2000).

Overt industrial conflict in the Netherlands is rare. According to official statistics, between 2005 and 2011 there were between 17 and 31 strikes annually, only about half of which were the result of conflicts in collective bargaining (CBS, 2012). The number of working days lost in this period was generally lower than that in most other European countries, peaking at 120.600 in 2008 and dropping as low as 4.600 in 2009 (Ibid., 2012). However, compared to other countries, industrial action in the Netherlands is often prevented by court rulings, which frequently appeal to potential harm to third-party interests (EIRO, 2002; EUROFOUND, 2012). 


\section{Data and measurements}

\section{Sample}

We gathered questionnaire survey data among negotiators involved in collective bargaining in the Netherlands (2011 Dutch Negotiator Survey). The data collection took place between October 2011 and January 2012. One hundred and fifty (150) collective agreements were selected via randomization from all existing Dutch collective agreements. The sampling frame was limited to agreements with starting dates from 1 January 2009 to 1 April 2011. This interval was chosen to minimize the risk of introducing retrospective bias while simultaneously minimizing the risk of selecting agreements for which negotiations were still in progress. ${ }^{3}$

We used all available documents related to the selected collective agreements to compile a list of contact data for the negotiators involved in the collective agreements. This initial list comprised 302 negotiators, who were invited via email to fill out an online questionnaire. For negotiators who had been involved in more than one of the selected collective agreements, we asked for information on only one of these agreements. A snowball question was included, asking for the names and contact information of the five most important other negotiators involved in bargaining for the agreement. These negotiators were subsequently also invited to participate. Combining these sampling methods, we were able to ask 409 negotiators to participate in our study, of which $58.1 \%$ were union representatives and $41.9 \%$ were firm representatives. 123 negotiators representing 73 of the 150 agreements completed the questionnaire. ${ }^{4}$ The distribution of union and firm negotiators and the representation of company and sector agreements in this sample were highly comparable to the sampling frame, and there were no indications of other sources of non-response bias.

\section{Measures}

\section{External information}

We set out to investigate the influence on negotiators of information on economic, organizational power and institutional indicators, as well as the influence of spillovers. To this end, we created two sets of items in our questionnaire.

As for the first set of items, we asked respondents whether the following types of information influenced them in general during collective bargaining: 1- "national employment levels"; 2- "local employment levels"; 3- "employment in the relevant sector" ; 4- "international pricing developments"; 5 - "national pricing developments"; 6- "pricing developments in the relevant sector"; 7- "international collective agreement developments"; 8- "national collective agreement developments"; 9- "collective agreement developments in the relevant sector"; 
10- "collective agreement developments in comparable companies"; 11- "local collective agreement developments"; 12- "employees' readiness for industrial action"; 13- "union strike funds"; and 14- "public opinion". When the response was positive, we asked the negotiators to rate how important that type of information was to them in general during collective bargaining, on a scale of "1" = "not very important" to " 5 " = "very important." We then recoded each of these issues into a variable with a six-point scale, where " 0 " represented "not mentioned as an influence," "1" represented "mentioned but not very important," and the maximum value of " 5 " represented "mentioned and very important."

The second set of items specifically examined the influence of information spillovers from other bargaining events. We asked the respondents to rate how strongly they agreed with nine statements. Three statements referred to information on the outcomes of other bargaining events. The other six items referred to information on conflict, divided into: $a$ - the readiness for industrial action and b- the success of industrial action. Furthermore, we differentiated each type of information according to three different possible sources: $a$ - the past experience of the bargaining unit, b- that of other companies in the same sector and c- that of other sectors. This yielded nine unique statements (see Table 1) for the measurement of spillovers, with possible answers ranging from " 1 " = "not at all" to " 5 "= "very much."

\section{Independent variables}

In order to test for differences between union and firm negotiators in the reported influence of external information, we created a variable with dummy coding for "union negotiator" (reference "firm negotiator"). To measure experience, for each negotiator, we calculated the number of years that he or she was active in col-

TABLE 1

Overview of Measurements of the Influence of Information on Other Bargaining Events

In general, during collective bargaining, I am influenced by information on...

Outcomes for the same collective agreement in the past

Outcomes for collective agreements in other companies in the same sector

Outcomes for collective agreements in other sectors

Past readiness for industrial action of the employees covered by the collective agreement

Readiness for industrial action of employees in other companies in the same sector

Readiness for industrial action of employees in other sectors

The success of industrial action for the same collective agreement in the past

The success of industrial action in other companies in the same sector

The success of industrial action in other sectors 
lective bargaining. As we asked the negotiators to report the influence that various types of external information had on them in general during collective bargaining, the measurement of bargaining unit characteristics was less straightforward. Negotiators in the Netherlands, especially union representatives, are often professionals who negotiate multiple collective agreements. We used the characteristics of the collective agreement for which the negotiators were selected into the sample as proxies and created a dummy variable for sector agreements, with company agreements as the reference category. This was based on the assumptions that negotiators will generally bargain for similar types of collective agreements.

\section{Control variables}

Little is known about possibly confounding factors that may affect the analysis of the influence of external information on negotiators. We proposed four, namely, age, gender, coverage of the agreement and the economic sector. Age is presumably positively associated with experience. Therefore, a tests of the relationship between experience and the influence of external information should control for potential life-cycle or cohort effects. Research suggests that there are gender differences in information processing (e.g. Graham, Myers and Stendardi, 2010). Consequently, we controlled our findings using a dummy variable for "female" (reference "male"). Because sector agreements generally cover a greater number of workers than company agreements, we also controlled for coverage using a variable that counted the number of workers to which the agreement applied. To account for different economic contexts, we included a categorical economic sector control with four categories; "primary," "secondary" (reference), "tertiary" and "quarternary."

\section{Analyses}

\section{Descriptive statistics}

\section{Characteristics of the collective agreements and the negotiators}

The 123 negotiators included in our sample represented 73 unique collective agreements. $53(72.6 \%)$ of these were company agreements, while $20(27.4 \%)$ were sector agreements. The distribution of the number of employees covered by these agreements was right skewed, with the first three quartiles consisting of agreements covering fewer than 5000 employees, while the largest agreements covered several hundred thousand employees. The median number of employees covered was 820.

Table 2 presents the descriptive statistics on the negotiators. $62 \%$ of the respondents were union negotiators, which does not deviate significantly from the proportion of union negotiators invited to participate. One fifth of the negotiators were female. The mean age was approximately 50 and on average the 


\begin{tabular}{lcrrrrr} 
TABLE 2 & & & & & \\
Descriptive Statistics Respondents & & & & & \\
& Valid N & Min. & Max. & Mean & $\begin{array}{r}\text { Standard } \\
\text { deviation }\end{array}$ \\
Negotiator's age & 123 & 27 & 65 & 49.69 & 8.24 \\
\hline Negotiator's gender female (ref. male) & 123 & 0 & 1 & 20.33 & \\
\hline Union negotiator (ref. firm negotiator) & 123 & 0.00 & 1.00 & 0.62 & \\
\hline Negotiator's experience & 123 & 2.00 & 32.00 & 12.91 & 7.50 \\
\hline Sector agreement (ref. company agreement) & 123 & 0 & 1 & 0.33 & \\
\hline Coverage & 123 & 18 & 819500 & 17892.20 & 77157.53 \\
\hline Economic sector (ref. secondary) & 123 & 0 & 1 & 0.08 & \\
\hline \begin{tabular}{l} 
Primary \\
\hline Tertiary
\end{tabular} & 123 & 0 & 1 & 0.41 & \\
\hline Quarernary & 123 & 0 & 1 & 0.07 & \\
\hline
\end{tabular}

Source: 2011 Dutch Negotiator Survey.

negotiators had 13 years experience with collective bargaining. One third of the negotiators were selected through a sector agreement. The median coverage of the agreements across the individual negotiators was 1500 employees.

The influence of economic, organizational power, and institutional information

Table 3 presents the descriptive statistics on the reported influence of information on employment developments, pricing developments and collective agreement developments on various levels, as well as the reported influence of information on militancy, strike funds and public opinion.

Regarding employment information, the highest mean was found for the influence of information on employment levels in the relevant sector. Lower values were found for information on national or local employment. We also found relatively high averages for the influence of information on national and sector pricing developments, especially compared to international pricing developments. These findings suggest that, besides being the dominant bargaining level, sector level economic developments were also the most important economic external influence on collective bargaining.

Organizational power indicators influenced the negotiators less than the economic indicators. Information on militancy was moderately influential while information on union strike funds and public opinion had a very limited influence. The comparatively low impact of organizational power indicators may be explained by the low levels of overt industrial conflict in the Netherlands, which limits the strategic value of such information. 
TABLE 3

Reported Influence of Economic, Organizational and Institutional Information

Valid N Min. Max. Mean

Employment developments

\begin{tabular}{|c|c|c|c|c|c|}
\hline National & 123 & 0 & 5 & 2.20 & 1.63 \\
\hline Sector & 123 & 0 & 5 & 3.39 & 1.56 \\
\hline Local & 123 & 0 & 5 & 2.03 & 1.68 \\
\hline
\end{tabular}

Pricing developments

\begin{tabular}{llllll} 
International & 123 & 0 & 5 & 1.84 & 1.62 \\
\hline National & 123 & 0 & 5 & 3.02 & 1.70 \\
\hline Sector & 123 & 0 & 5 & 3.14 & 1.74 \\
\hline
\end{tabular}

Organizational indicators

\begin{tabular}{llllll} 
Militancy & 123 & 0 & 5 & 2.52 & 1.78 \\
\hline Strike funds & 123 & 0 & 5 & 1.07 & 1.19 \\
\hline Public opinion & 123 & 0 & 5 & 1.56 & 1.43
\end{tabular}

Collective agreement developments

\begin{tabular}{llllll} 
International & 123 & 0 & 5 & 1.41 & 1.41 \\
\hline National & 123 & 0 & 5 & 3.66 & 1.15 \\
\hline Sector & 123 & 0 & 5 & 3.64 & 1.37 \\
\hline Local & 123 & 0 & 5 & 1.88 & 1.77 \\
\hline Comparable companies & 123 & 0 & 5 & 3.34 & 1.71 \\
\hline
\end{tabular}

Source: 2011 Dutch Negotiator Survey.

National and sectoral collective agreement developments were highly influential, clearly reflecting both the multileveled nature of bargaining as well as the importance of sector agreements. In the context of increasing Europeanization and the openness of the Dutch economy, international collective agreement developments may be expected to play a significant role. Indeed, $63.41 \%$ of the negotiators reported that they were influenced by them. However, they were on average rated to be considerably less influential than national and sectoral developments. Local developments were also reported to have a rather modest influence, which suggests that, possibly related to the small country size, no substantial geographical dynamics were at play in the collective bargaining. However, we did find a very high mean value for the influence of information on collective agreement developments in other, comparable companies. Despite the lack of formal pace-setting, this suggests that there was a substantial amount of spillover across different bargaining units. A more detailed analysis of what these spillovers entailed is presented in the next section. 


\section{The influence of spillovers}

We measured the influence of spillover containing information on: 1) outcomes; 2) the readiness of employees for industrial action; and 3) the success of industrial action; with each relating to: 1 - the past experience of the same bargaining unit; 2 - that of other companies in the same sector; or 3- that of other sectors. The item nonresponse for these measurements varied between $6 \%$ and $21 \%$. Additional analyses of the missing cases did not indicate any obvious non-response bias. Descriptive statistics for the nine measurements are presented in Table 4.

Overall, information on outcomes had more influence than information on the readiness for, and success of industrial action. The level of influence also increased with proximity of the source of information, i.e. the past experience of the bargaining unit was rated to be more important than that of other companies in the same sector, while that of other sectors had the least impact. Paired $t$-tests indicated that these differences were all statistically significant $(p<0.01$, two-tailed) with mean differences ranging between 0.5 and 0.8 points. This supports hypothesis $\mathrm{H} 1$, predicting that influence would increase with proximity.

We found the highest mean score for the reported influence of information on bargaining outcomes for the same collective agreement in the past with a mean value of almost four on a five-point scale. This finding strongly supports history-dependent wage theories. In line with theories of wage spillover, there was also substantial evidence for spillovers across bargaining units, especially

TABLE 4

Reported Influence of Spillover from Other Bargaining Events

\begin{tabular}{|c|c|c|c|c|c|}
\hline & Valid N & Minimum & Maximum & Mean & $\begin{array}{l}\text { Standard } \\
\text { deviation }\end{array}$ \\
\hline Outcomes same collective agreement past & 116 & 1 & 5 & 3.97 & 1.08 \\
\hline $\begin{array}{l}\text { Outcomes collective agreements other } \\
\text { companies same sector }\end{array}$ & 115 & 1 & 5 & 3.47 & 1.34 \\
\hline $\begin{array}{l}\text { Outcomes for collective agreements } \\
\text { other sectors }\end{array}$ & 110 & 1 & 5 & 3.07 & 1.16 \\
\hline Past readiness for industrial action & 108 & 1 & 5 & 3.38 & 1.32 \\
\hline $\begin{array}{l}\text { Readiness for industrial action other } \\
\text { companies same sector }\end{array}$ & 111 & 1 & 5 & 2.57 & 1.35 \\
\hline Readiness for industrial action other sectors & 101 & 1 & 5 & 2.07 & 1.06 \\
\hline Past success of industrial action & 98 & 1 & 5 & 3.46 & 1.36 \\
\hline $\begin{array}{l}\text { Success of industrial action other companies } \\
\text { same sector }\end{array}$ & 107 & 1 & 5 & 2.71 & 1.33 \\
\hline Success of industrial action other sectors & 97 & 1 & 5 & 2.12 & 1.10 \\
\hline
\end{tabular}

Source: 2011 Dutch Negotiator Survey. 
within the same sector. However, the informational content of spillovers was not limited to outcomes. Information on conflict in other bargaining events also influenced the negotiators considerably, as indicated by the mean values for the items measuring the influence of information on the employees' readiness for, and the success of industrial action. Here too, the influence increased when sources were more proximate. These results lend empirical credence to theories that build on the assumption that conflicts in labour relations are interrelated, such as diffusion theory (c.f. Lehr et al., 2014) and theories on learning from conflict (e.g. Mauro, 1982, Schnell and Gramm, 1987; Kuhn and Guhn, 1999).

\section{Explaining differences in the influence of external information ${ }^{5}$}

To test our remaining hypotheses, we estimated (OLS) multivariate linear regression models for each of the external information measurements. Every model included main effects for the union negotiator dummy, negotiator experience, age, the female gender dummy, the sector agreement dummy, the log-transformed coverage variable and three dummies controlling for economic sector. We used standard errors that were robust to heteroscedasticity of the residuals (White, 1980) for significance tests. For reasons of interpretability and space, only the coefficients for statistically significant effects are reported. ${ }^{6}$ Given constraints on statistical power due to the sample size and the directed nature of our hypotheses, we took $\alpha=0.10$ (two-tailed) as the critical value.

Prior to the model estimations, we analyzed the bivariate associations between all independent and dependent variables by calculating Pearson's correlation coefficients and applying independent sample t-tests where appropriate. These statistics are not presented here in full but we report any statistically significant (based on a liberal one-tailed critical value of $\alpha=0.10$ ) bivariate association between the dependent and independent variables that did not persist in the multivariate analyses. In this way, we aim to provide both stringent hypotheses tests as well more tolerant descriptions of associations in our data. For the spillover measurements, the missing cases may reasonably be assumed to be missing at random and ignorable. As there were no missing cases on the independent variables, we used complete case analyses, which under these conditions can be considered to be unbiased and cannot be improved upon (Allison, 2001).

\section{Explanatory analyses}

Table 5 lists the estimates for the models explaining each of the general types of external information. Hypothesis $\mathrm{H} 2$ predicted that external information would have more influence on union negotiators than on firm negotiators. This hypothesis was partially supported by our findings. The reported influence of sectoral and local employment developments, and militancy were all higher for union negotiators. 


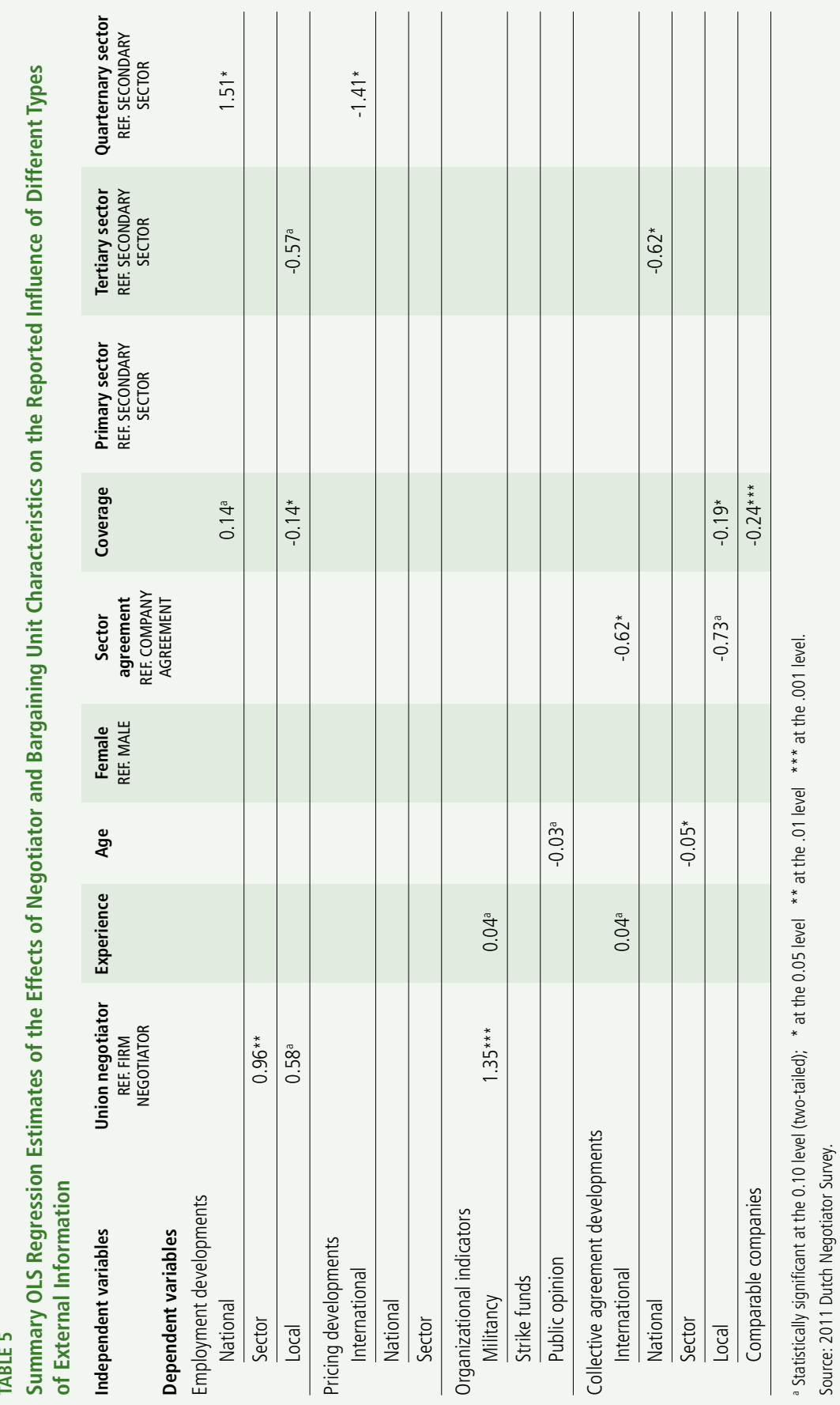


The effect was particularly large for militancy, where the predicted value on a sixpoint scale was 1.35 points higher for union negotiators than for firm negotiators. The bivariate analyses suggest that information on national employment developments, strike funds, collective agreement developments in comparable companies also had more influence on union than on firm negotiators.

We tested competing hypotheses concerning the direction of the association between experience and the influence of external information $(\mathrm{H} 3 \mathrm{a} / \mathrm{b})$. The results of the multivariate analyses indicate that experience had statistically significant but small positive effects on the reported influence of militancy and international collective agreement developments. Modest positive bivariate correlations between experience and the influence of local employment developments, as well as international and national pricing developments were found. These results run against the hypothesis that, as experience increases, the influence of external information decreases (H3a) but offer some support for the alternative hypothesis that this influence increases as negotiators become more experienced (H3b).

Within a single mixed bargaining system, we found very limited support for the proposition that sector bargaining is less influenced by its wider economic environment than company bargaining $(\mathrm{H} 4)$. Controlling for other factors, negotiators in sector agreements were not found to be less affected by economic information than negotiators in company agreements. However, the mean of the reported influence of information on sectoral and local employment developments was found to be lower for sector bargaining than for company bargaining in the biviarate analyses.

The influence of information on both international and local collective agreement developments was lower for negotiators in sector agreements than for negotiators in company agreements. These findings partially support hypothesis $\mathrm{H} 5$ and also suggest that, although the influence of international developments was limited, it was stronger for the generally more internationally exposed bargaining units that bargain individually. Also in line with hypothesis 5 , the influence of collective agreement developments in comparable companies was also found to be lower for negotiators in sector bargaining, but only in our bivariate analyses.

Table 6 summarizes the statistically significant effects on our nine measures of spillover as found in the multivariate analyses. On the whole, we found more support for the hypothesis that external information has more influence on union negotiators than on firm negotiators $(\mathrm{H} 2)$, at least regarding conflict-related information on other bargaining events. In particular, the predicted influences of information on past readiness for, and the success of industrial action was higher for union negotiators by approximately one point on a five-point scale. Similarly, information on the readiness for, and success of industrial action in other companies in the same sector and in other sectors had more influence on union negotiators, although here the differences were less extreme. 


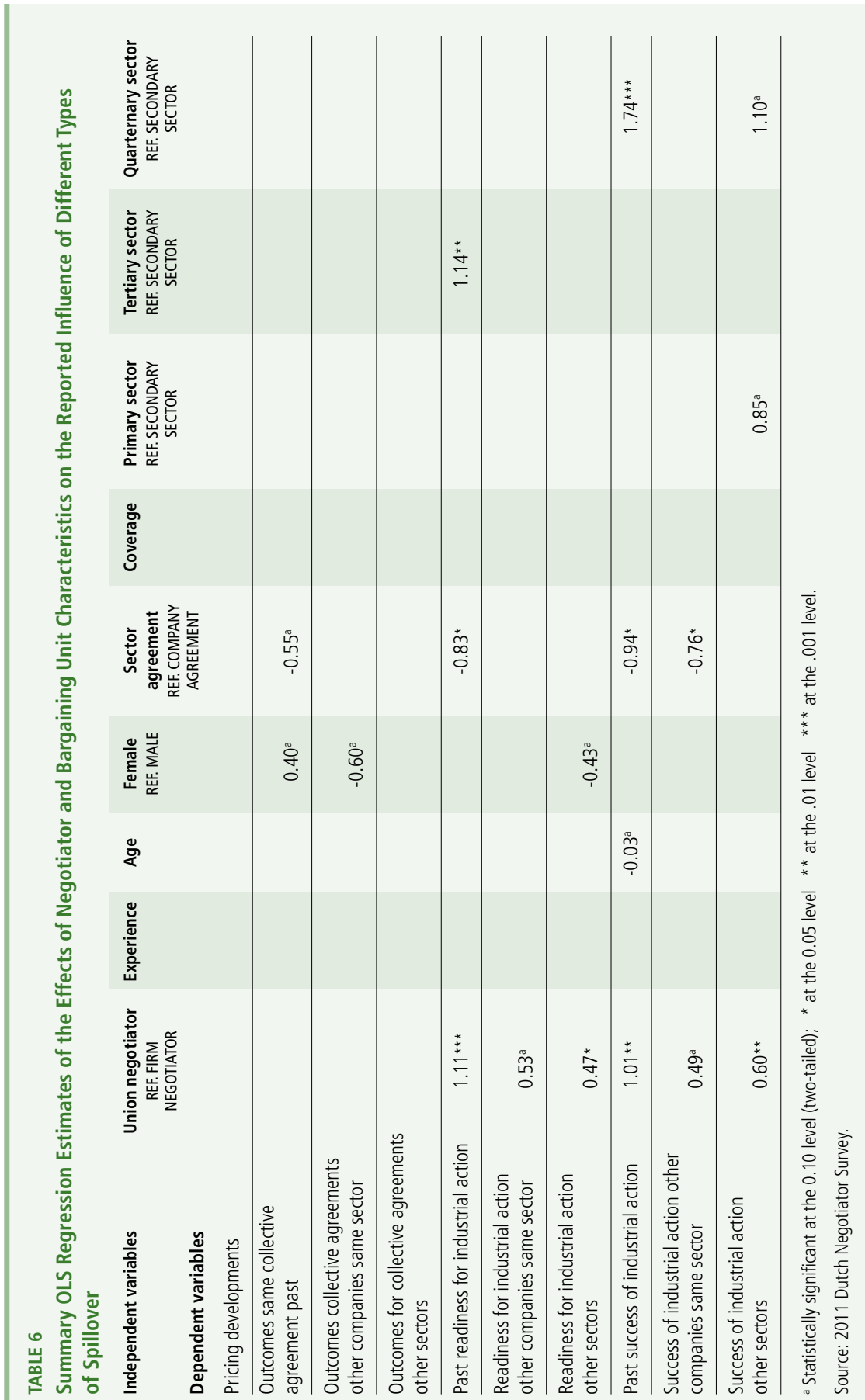


Surprisingly however, the two types of negotiators did not differ significantly regarding the reported influence of information on outcomes in other bargaining events, controlling for other factors. This suggests that effects which are traditionally often ascribed to the formation of reference points by workers and unions, i.e. wage spillovers and state-dependency of wages, may actually have affected both sides of the bargaining table equally. This may be because employers correctly anticipate the importance of such reference points to their counterparts (c.f. Bewely, 1999), but it may also be the case that firm negotiators themselves are guided by external reference points rather than strictly by internal information on viable outcomes. However, it must be noted that bivariate tests did point towards more influence on union negotiators compared to firm negotiators for information on outcomes in other companies in the same sector and in other sectors.

We found no further evidence of the hypothesis that the influence of external information increases with experience $(\mathrm{H} 3 \mathrm{~b})$ in our multivariate analyses, while bivariate tests even hinted at a negative correlation between the influence of the success of industrial action in other sectors and negotiator experience.

As predicted in hypothesis $\mathrm{H} 5$, spillovers had less influence on negotiators in sector bargaining than in company bargaining. The multivariate analyses suggested that this was the case for the influence of past outcomes, as well as past readiness for, and the success of industrial action, and the success of industrial action in other companies in the same sector. However, the bivariate analyses did not show a uniform pattern. While the influence of outcomes in the same sector was lower in company bargaining than in sector bargaining, the influence of outcomes in other sectors and the readiness for industrial action in the same sector was actually higher.

\section{Conclusion and discussion}

The impetus for this research was the surprising lack of comparable empirical data on the influence of external information on union and firm negotiators, given the importance attributed to this information in theories explaining the outcomes and conflicts in collective bargaining. Using a standardized survey questionnaire measuring the influence of external information in the Netherlands, we sought to address two research questions: 1- to what extent are negotiators in collective bargaining influenced by different types of external information?; and 2- how can differences in the reported influence of external information between negotiators be explained by the characteristics of the negotiators and bargaining units?

Our analyses revealed a multifaceted picture of the influence of external information on collective bargaining. Economic indicators (i.e. employment and pricing developments), particularly those operating at the sector level, had substantial influence on negotiators. Information on national and sectoral collective agreement 
developments was also very influential, while indicators reflecting organizational power, i.e. militancy, strike funds and public opinion, were less important.

Another major influence on negotiators was information on other bargaining events, i.e. spillovers. We differentiated spillovers according to their source and informational content and found that information on outcomes had more influence than information on the readiness for, and success of industrial action. The hypothesis that influence increases with the proximity of the source of spillover was also strongly supported, with information on the past experience of the bargaining unit having more influence than information on other bargaining units within the same sector, while information on other sectors had the least influence. These findings provide empirical underpinnings for theories assuming that bargaining events influence each other, but also highlight the importance of distinguishing between sources and types of information spillover.

We found considerable evidence in favour of the hypothesis that union negotiators are generally more influenced by external information than firm negotiators. Union negotiators appeared to be particularly more concerned with information on local and sectoral employment, and militancy. They were also more influenced by spillovers, particularly when the content of these was related to conflict.

It was not a priori clear what type of relationship between experience and influence of external information to expect. Our findings suggest that more experienced negotiators were more influenced by some types of external information, i.e. militancy and international collective agreement developments, but the associations were of rather modest size.

We found little evidence suggesting that sector bargaining was less affected by its wider economic environment than company bargaining. However, negotiators in sector bargaining were less affected by international and local collective agreement developments and some types of spillover than those in company bargaining, suggesting that sector bargaining operates with relatively more autonomy.

Recent studies have documented that across European countries, specific sectors are converging (Bechter et al., 2012) and appear to be affected by transnational wage coordination (e.g Traxler and Brandl, 2009; Ramskogler, 2012; Glassner and Pusch, 2013). Our findings suggests that the impact of international collective agreement developments in the Netherlands is still modest compared to the impact of developments within the country, but the sample did not allow for a sufficiently fine-grained sector-classification to identify particular sectors that were more internationally influenced. However, our findings of modest international spillovers, coupled with substantial within-country spillovers, suggest that it may be important to consider indirect effects that may result when influential wage leaders within a country are themselves affected by international developments. 
Our analyses of the questionnaire survey data yielded an empirical basis for a number of assumptions and tacit understandings commonly found in employment relations literature. The cross-sectional analysis of a single country presented here shows that obtaining information from negotiators directly offers interesting insights into collective bargaining. Some of our findings seem to reflect the specific national context in which we collected our data, i.e. dominant sector bargaining, a multileveled collective bargaining system and relatively low levels of industrial conflict. Hence, analyses of the influence of external information in different institutional and economic settings may provide important additional insights. It is therefore our hope that future research will replicate our analyses in different periods and contexts and that large-scale country comparative surveys will incorporate our design. Future research should also consider the effects of external information on the outcomes of, and conflicts in collective bargaining (c.f. Lehr et al., 2015).

\section{Notes}

1 In the Netherlands, union density is comparatively low, yet collective agreement coverage is high. The consequences of bargaining thus extend beyond union members (Hartog, Leuven and Teulings, 2002). Moreover, in the case of industrial action, participation is not limited to union members. In fact, it may be used as a tool to attract new members (Akkerman, 2008). The readiness of employees to participate may therefore be considered a better indicator of bargaining power than unionization.

2 Information on militancy may be considered internal rather than external. We chose to include it nevertheless. In contrast to the other factors we analyzed, this factor was not by definition contextual but was also an attribute of the bargaining unit. Presumably, the militancy of the employees within a bargaining unit is likely to be considered of more importance than that of employees elsewhere.

3 Holdouts, i.e. continued negotiation over a new agreement after the old agreement has expired, are common in the Netherlands. During holdouts, the old agreement remains intact, while the eventual new agreement is usually backdated to coincide with the end date of the old agreement (c.f. Ours and Wijngaert, 1996).

4 Two negotiators were involved in a public sector agreement. As a robustness check, all findings reported here were replicated with these negotiators excluded from the sample.

5 An appendix fully detailing all the analyses summarized here is available from the first author upon request.

6 We present the full analyses of each type of external information separately, in line with the aim of this manuscript to provide extensive analyses of all types of external information.

\section{References}

Abowd, John. 1989. "Collective Bargaining and the Division of the Value of the Enterprise." NBER Working Papers 2137. National Bureau of Economic Research. 
Allison, Paul. 2001. Missing Data. Thousand Oaks: Sage.

Ashenfelter, Orey and George Johnson. 1969. "Bargaining Theory, Trade Unions, and Industrial Strike Activity." American Economic Review, 59 (1), 35-49.

Akkerman, Agnes. 2000. "Verdeelde vakbewegingen en stakingen: Concurrentie om leden. (Divided Labor Movement: Competition for Members)". Amsterdam: Thela Thesis.

Akkerman, Agnes. 2008. "Union Competition and Strikes: The Need for an Analysis at the Sector Level." Industrial and Labor Relations Review, 61 (4), 445-459.

Babcock, Linda, John Engberg and Robert Greenbaum. 2005. "Wage Spillovers in Public Sector Contract Negotiations: The Importance of Social Comparisons." Regional Science and Urban Economics, 35 (4), 395-416.

Bechter, Barbera, Bernd Brandl and Guglielmo Meardi. 2012. "Sectors or Countries? Typologies and Levels of Analysis in Comparative Relations." European Journal of Industrial Relations, 18 (3), 185-202.

Bewley, Truman. 1999. Why Wages don't Fall during a Recession. Cambridge: Harvard UP.

Blanchflower, David and Andrew Oswald. 1988. "Internal and External Influences Upon Pay Settlements." British Journal of Industrial Relations, 26 (3), 363-370.

Calmfors, Lars and John Driffhill. 1988. "Bargaining Structure, Corporatism and Macroeconomic Performance." Economic Policy, 3 (6), 13-61.

Campolieti, Michele, Robert Hebdon and Douglas Hyatt 2005. "Strike Incidence and Strike Duration: Some New Evidence from Ontario." Industrial and Labor Relations Review, 58 (4), 610-680.

Chamberlain, Neil and James Kuhn.1986. Collective Bargaining. NY: McGraw-Hill.

Card, David. 1990. "Strikes and Bargaining: A Survey of the Recent Empirical Literature." The American Economic Review, 80 (2), 410-415.

CBS. 2012. Statline: Werkstakingen; diverse kenmerken. < http://statline.cbs.nl/StatWeb/p ublication $/$ ? VW $=T \& D M=S L N L \& P A=60061$ ned $\& D 1=a \& D 2=a \& D 3=a, ! 0-4 \& H D=120423-$ 1522\&HDR=T,G2\&STB=G1 > (accessed November 27, 2012).

Christofides, Louis, Robert Swidinsky and David Wilton. 1980. "A Microeconomic Analysis of Spillover with the Canadian Wage Determination Process." Review of Economics and Statistics, 62 (2), 213-221.

Clegg, Hugh. 1976. Trade Unionism Under Collective Bargaining. Oxford: Blackwell.

Cousineau, Jean-Michel and Robert Lacroix. 1986. "Imperfect Information and Strikes: An Analysis of the Canadian Experience, 1967-1982." Industrial and Labor Relations Review, 39 (3), 377-387.

Cramton, Peter and Joseph Tracy. 2003. "Unions, Bargaining and Strikes." In Addison, J. and Schnabel, C. (eds.) International Handbook of Trade Unions, Cheltenham: Edward Elgar.

Dunlop, John. 1957. "The Task of Contemporary Wage Theory." In Dunlop, J. (eds.) The Theory of Wage Determination. London: Macmillan.

EIRO. 2002. Netherlands: Latest Developments in Strikes. < http://www.eurofound.europa.eu/ eiro/2002/09/feature/nl0209103f.htm > (accessed November 27, 2012).

EIRO. 2008. Netherlands: Right to Strike. < http://www.eurofound.europa.eu/emire/NETHERLANDS/ RIGHTTOSTRIKE-NL.htm> (accessed November 27, 2012). 
EUROFOUND. 2012. The Netherlands: Industrial Relations Profile. < http://www.eurofound. europa.eu/eiro/country/netherlands.htm > (accessed November 27, 2012).

Festinger, Leon. 1954. "A Theory of Social Comparison Processes". Human Relations, 7 (2), 117-140.

Frank, Robert. 1984. "Are Workers Paid their Marginal Products?" The American Economic Review, 74 (4), 549-571.

Franzosi, Roberto. 1989. "One Hundred Years of Strike Statistics." Industrial and Labor Relations Review, 42 (3), 34-63.

Glassner, Vera and Toralf Pusch. 2013. "Towards a Europeanization of Wage Bargaining? Evidence from the Metal Sector." European Journal of Industrial Relations, 19 (2): 145-160.

Graham, Judy, Joan Myers and Edward Stendadri. 2010. "Gender Differences in Information Processing and Financial Statement Interpretation." Journal of Business and Behavioral Sciences, 22 (1), 181-196.

Hartog, Joop, Edwin Leuven and Coen Teulings. 2002. "Wages and Bargaining Regime in a Corporatist Setting: the Netherlands." European Journal of Political Economy, 18 (2), 317-331.

Hayes, Beth. 1984. "Unions and Strikes with Asymmetric Information." Journal of Labor Economics, 2 (1), 57-83.

Heckman, James. 1991. "Identifying the Hand of Past: Distinguishing State Dependence from Heterogeneity." American Economic Review, 81 (2), 276-298.

Hicks, John. 1932. The Theory of Wages. NY: MacMillan.

Hyman, Richard and lan Brough. 1975. Social Values and Industrial Relations: A Study of Fairness and Inequality. Oxford: Blackwell.

Kaufman, Bruce. 2002. "Models of Union Wage Determination: What Have We Learned Since Dunlop and Ross?" Industrial Relations, 41 (1), 110-158.

Kuhn, Peter and Wulong Gu. 1999. "Learning in Sequential Wage Negotiations: Theory and Evidence." Journal of Labor Economics, 17 (1), 109-140.

Leap, Terry and David Grigsby. 1986. "A Conceptualization of Collective Bargaining Power." Industrial and Labor Relations Review, 39 (2), 202-213.

Lehr, Alex, Jana Vyrastekova, Agnes Akkerman and René Torenvlied. 2013. "Spillover and Conflict in Wage Bargaining: Experimental Evidence," Paper presented at the European Sociological Association Conference, Torino.

Lehr, Alex, Agnes Akkerman and René Torenvlied. 2015. "Spillover and Conflict in Collective Bargaining: Evidence from a Survey of Dutch Union and Firm Negotiators." Work, Employment \& Society: 095001701452123 (forthcoming).

Manski, Charles. 1993. "Identification of Endogenous Social Effects: The Reflection Problem." The Review of Economic Studies, 60 (3), 531-542.

Martin, Roderick. 1992. Bargaining Power. Oxford: Oxford UP.

Mauro, Martin. 1982. "Strikes as a Result of Imperfect Information." Industrial and Labor Relations Review, 35 (4), 522-538.

Mitchell, Daniel. 1982. "How to Find Wage Spillovers (Where None Exist)." Industrial Relations, 21 (3), 392-397. 
Montgomery, Edward and Mary Benedict. 1989. "The Impact of Bargainer Experience on Teacher Strikes." Industrial and Labor Relations Review, 42 (3), 380-392.

Olson, Mancur. 1982. The Rise and Decline of Nations. New Haven: Yale UP.

Ours, Jan van and Rob Wijngaert. 1996. "Holdouts and Wage Bargaining in the Netherlands." Economics Letters, 53 (1), 83-88.

Ramskogler, Paul. 2012. "Is there a European Wage Leader? Wage Spillovers in the European Monetary Union." Cambridge Journal of Economics, 36, 940-962.

Reder, Melvin and George Neumann. 1980. "Conflict and Contract: The Case of Strikes." Journal of Political Economy, 88 (5), 867-886.

Rees, Albert. 1993. "The Role of Fairness in Wage Determination." Journal of Labor Economics, 11 (1), 243-525.

Rij, Coen van and Maurci Rojer. 1998. Follow the leader? Een analyse van volging en coördinatie van afspraken over loonstijgingen in CAO's. The Hague: SWZ.

Rojer, Maurice. 2002. De betekenis van de CAO en het algemeen verbindend verklaren van CAO's. The Hague: SWZ.

Schnell, John and Cynthia Gramm. 1987. "Learning by Striking: Estimates of the Teetotaler Effect." Journal of Labor Economics, 5 (2): 221-241.

Shorter, Edward and Charles Tilly. 1974. Strikes in France, 1830-1968. Cambridge: Cambridge UP.

Skeels, Jack and Paul McGrath. 1997. "The Effect of Union Financial Strength and Liquidity on Strike Propensity." The Journal of Economics, 23 (3): 59-71.

Svejnar, Jan. 1986. "Bargaining Power, Fear of Disagreement, and Wage Settlements: Theory and Evidence from the U.S. Industry." Econometrica, 54 (5): 1055-1078.

Torenvlied, René and Agnes Akkerman 2004. "Theory of 'Soft' Policy Implementation in Multilevel Systems with an Application to Social Partnership in the Netherlands." Acta Politica, 39 (1), 31-58.

Traxler, Franz and Bernd Brandl. 2009. "Towards Europeanization of Wage Policy: Germany and the Nordic Countries." European Union Politics, 10, 177-201.

Traxler, Franz. 2003. "Coordinated bargaining: a stocktaking of its preconditions, practices and performance." Industrial Relations Journal, 34 (3), 194-209.

Traxler, Franz, Bernd Brandl and Vera Glassner. 2008. "Pattern Bargaining: An Investigation into its Agency, Context and Evidence." British Journal of Industrial Relations, 46 (1), 33-58.

Tversky, Amos and Daniel Kahneman. 1981. "The Framing of Decisions and the Psychology of Choice." Science, 211 (4481), 453-458.

Walton, Richard and Robert McKersie. 1965. A Behavioral Theory of Labor Negotiations. New York: IRL Press.

White, Halbert. 1980. "A Heteroskedasticity-Consistent Covariance Matrix Estimator and a Direct Test for Heteroskedasticity." Econometrica, 48 (4), 817-838. 


\section{The Influence of External Information on Collective Bargaining: Survey Evidence of Union and Firm Negotiators in the Netherlands}

This paper seeks to answer two questions: 1 - To what extent are negotiators in collective bargaining influenced by different types of external information? 2How can differences in the influence of external information between negotiators be explained by the characteristics of the negotiators and bargaining units? A standardized questionnaire measuring self-reported influences of different types of external information was developed and administered to a representative sample of union and firm negotiators in the Netherlands. In total, 123 negotiators participated in the survey. Four types of external information were investigated: 1- economic information; 2- information on organizational power; 3- institutional information; and 4-information spillovers. Descriptive analyses show that economic information, particularly when referring to the sector level, was very influential, as was institutional information on national and sectoral collective agreement developments. Information reflecting organizational power, e.g. militancy, carried less weight, while information on other bargaining events, i.e. spillover, was also very important. From extant theory, empirical findings and common assumptions in labour relations literature, the paper developed and tested a number of hypotheses concerning the influence of external information. It was found that the influence of spillovers increased with the proximity of their source. Union negotiators were generally more influenced by external information than firm negotiators. There was some evidence that influence increased with experience, but this effect was rather modest. Evidence that negotiators in sector bargaining were less affected by the economic environment than negotiators in company bargaining was weak, but they were found to be less influenced by spillovers and international collective agreement developments.

KEYWORDS: collective bargaining, negotiators, information, survey, spillover.

\section{RÉSUMÉ}

\section{L'influence de l'information externe sur la négociation collective : résultats d'une enquête auprès de négociateurs syndicaux et patronaux aux Pays-Bas.}

Cet article cherche à répondre à deux questions: 1- dans quelle mesure les personnes négociant une convention collective sont-elles influencées par divers types d'information externe; et 2- comment les différences d'influence de l'information externe entre les personnes négociatrices peuvent être expliquées par les caractéristiques de ces personnes et les unités de négociation. Un questionnaire standardisé cherchant à mesurer les influences auto-déclarées de divers types d'infor- 
mation externe a été développé et administré à un échantillon représentatif de négociateurs et négociatrices de syndicats et d'employeurs dans les Pays-Bas. Au total, 123 négociateurs ont participé à l'enquête.

Quatre types d'information externe ont été étudiés: 1- information de nature économique; 2- information relative au pouvoir organisationnel; 3- information de nature institutionnelle; et 4 information relative aux effets de débordement des négociations. Les analyses descriptives montrent que l'information de nature économique, particulièrement au niveau sectoriel, s'avère très influente, tout comme l'information de nature institutionnelle portant sur les développements nationaux et sectoriels des conventions collectives. L'information reflétant le pouvoir organisationnel, tel le militantisme, aurait moins de poids, alors que l'information concernant d'autres aspects liés à la négociation - par exemple, l'effet de débordement - $\mathrm{s}^{\prime}$ avère très important.

Selon la théorie existante provenant de résultats de recherches empiriques et d'hypothèses couramment admises dans la littérature des relations de travail, cet article développe et vérifie un certain nombre d'hypothèses concernant l'influence de I'information externe. II s'avère que l'influence des effets de débordement s'accroit à mesure qu'on se rapproche de leur source. De plus, les négociateurs syndicaux sont généralement davantage influencés par l'information externe que leurs visà-vis patronaux. Il appert aussi que l'influence s'accroît avec l'expérience, bien que cet effet demeure modeste. L'idée que les personnes négociant au niveau sectoriel sont moins influencées par l'environnement économique que celles négociant au niveau de l'entreprise n'est pas vraiment accréditée par les résultats. Dans cette enquête, il ressort qu'elles sont moins influencées par les effets de débordement et par les développements de convention collective au niveau international.

Mots-clés : négociation collective, négociateurs, information, enquête, retombées.

\section{RESUMEN}

\section{La influencia de la información externa sobre la negociación colectiva: Resultados de una encuesta con negociadores sindicales y patronales en los Países Bajos}

Este artículo pretende responder dos preguntas: 1- ¿Hasta qué punto los negociadores de la convención colectiva son influenciados por los diferentes tipos de información externa? 2- ¿Las diferencias en la manera cómo la información externa influencia los negociadores pueden ser explicadas por las características de dichos negociadores y de las unidades de negociación? Un cuestionario estandarizado fue elaborado con medidas auto-reportadas de la influencia de los diferentes tipos de información externa. El instrumento fue administrado a una muestra representativa de negociadores sindicales y patronales en los Países Bajos, obteniendo la participaron de un total de 123 negociadores. Cuatro tipos de información externa fueron investigados: 1- la información económica; 2- la información sobre 
el poder organizacional; 3- la información institucional; y 4- las externalidades de la información. Los análisis descriptivos que la información económica, particularmente aquellas que conciernen el sector, fueron muy influentes, mientras que la información institucional influenció el desarrollo de la negociación a nivel nacional y sectorial. La información sobre el poder organizacional, por ejemplo, el militantismo, tuvo un peso menos importante, mientras que la información sobre otros aspectos de la negociación, tales que las externalidades, fue también muy importante. A partir de la teoría, los resultados empíricos y los postulados comunes en la literatura sobre relaciones laborales, el artículo desarrolló y verificó algunas hipótesis sobre la influencia de la información externa. Fue corroborado que la influencia de las externalidades aumenta con la proximidad de la fuente. Los negociadores sindicales fueron en general más influenciados por la información externa que los negociadores patronales. Los resultados sugieren que la influencia se incrementa con la experiencia pero este efecto fue más bien modesto. Fue también débil el resultado indicando que los negociadores de nivel sectorial fueron menos afectados por el contexto económico que los negociadores de nivel empresarial. Pero la evidencia fue sólida en el sentido que los negociadores de nivel sectorial fueron menos influenciados por las externalidades y el desarrollo de la negociación colectiva internacional.

PALABRAS CLAVES: negociación colectiva, negociadores, información, encuesta, externalidades. 